\title{
Demand for Money Function in Case of Philippines: An Empirical
}

\section{Analysis}

\author{
Chayanan Kerdpitak ${ }^{1}$ \\ ${ }^{1}$ Suan Sunandha Rajabhat University, Bangkok, Thailand \\ Correspondence: Dr. Chayanan Kerdpitak, Suan Sunandha Rajabhat University, Bangkok, Thailand. E-mail: \\ Chayanan.ke@ssru.ac.th
}

Received: February 27, 2020

Accepted: March 23, 2020

Online Published: March 28, 2020

doi:10.5430/rwe.v11n1p220

URL: https://doi.org/10.5430/rwe.v11n1p220

\begin{abstract}
An effective formulation of monetary policy provides an empirical and coherent model of money related with demand. In order for the monetary authorities to understand the demand for the purpose of money function, the steadiness of money demand is important as it leads towards an application of efficient monetary policy. In order to examine the stability of money demand function of Philippines, following study was conducted with broad money, real asset price index, GDP deflator, real GDP, long-term interest rate and short-term interest rate. For empirical investigation, unit root test, cointegration, and Granger-Causality tests were used. However, the findings of the cointegration suggests that cointegration reveals there is presence of linear combinations, and results shows that there are four cointegrating equations present. Therefore, it is evident that there are at least 4 cointegrating relations between the variables. Hence, some of macroeconomic indicators can be used to predict the broad money due to presence of vector. However, the Granger-Causality shows that no macroeconomic variable granger cause broad money (M1). Therefore, the selected macroeconomic indictors RS, LS, CPI, GDP deflator, RGDP and AP/P cannot be used to predict the variation in the broad money (M1) in case of Philippines. This means the money demand function in Philippines is not stable, and for this purpose further investigation is suggested by increasing sample size and time window in quarterly or semi-annually.
\end{abstract}

Keywords: demand for money, Philippines

\section{Introduction}

An effective formulation of monetary policy provides an empirical and coherent model of money related with demand. In order for the monetary authorities to understand the demand for the purpose of cash function, the steadiness of demand for money is important as it leads towards an application of efficient monetary policy. For the economic growth, the fluctuations in money demand can however lead towards the economic counterbalance whereas this risk can be mitigated through managing demand for the reaching effective money function (Udeh, Nwude and Offor, 2018). Despite this significance of money functions, there is a lack of evidence found with regard to how it is functioning in the case of Philippines. Previous researches have focused on this area of the study; however, these studies have differed in terms of context. For instance, Shafiq and Malik (2018) selected Pakistan as the context of the study whereas Yu and Gan (2009) have focused on ASEAN countries. Moreover, the study of Inoue and Hamori (2008) has focused on the context of India in order to conduct their research. Therefore, this research is based on conducting a practical analysis of demand for function of money in the context of Philippines.

\section{Literature Review}

There has been a significant debate between Monetarist and Keynesian economists. Keynesian economists have established a model on the notion that money should be kept for national, business and preventative purposes whereas real income as well as nominal transactions should be considered as an important reasons for maintaining balances in money (Keynes, 1936). On the other hand, the monetarist tradition was introduced by Friedman that further converted wealth constraints into basic function of demand. Friedman has criticised model of Keynes by introducing yields on human capital, non-human goods, bonds, financial assets and equities (Edet, Udo and Etim, 2017). Chick (2015) has further supported the idea of Friedman where money demand is dependent on income return and assets 
The cash demand describes the role of income besides prices in terms of a rising income will aid the increment of money demanded. While in case of holding inventory, the demand for money exists within the inventory till the company gets paid for it. The literature of this study describes about different theories related to need for money and how such demand exists in various countries (Jonung, 2018).

\subsection{Money Demand Theories}

There are five major theories related to the money demand that demonstrates the money demand function. The first theory is the theory of classical economists that describes the quantity theory of money which was provided by an economist in his book, named Irving Fisher collection of Purchasing Power of Money (1911). This theory of fisher relates to one basic understanding according to fisher which is other things remaining unaffected, the circulation of money increases with the level of price increase that is directly proportional while the value of money falls and vice versa. Fisher describes the quantity theory of money with an equation of exchange that is MV=PT. This equation of fisher describes the demand for money in terms of stating about the sum amount of money circulated is equal to the value of transactions being undertaken in the economy. It also tells that the demand for money also depends on the demand and supply like other commodities. As money performs the major function of being a medium of exchange of goods and services while this quantity theory of Fisher has certain interrelated propositions (Dimand, 2019). One of the propositions is the connection between money and level of prices for which the constancy of the demand for money is overbearing. Then changes in money supply (M) leads to changes in the level of prices $(\mathrm{P})$ in terms of inflation since demand rises and as compared to demand, supply is short. The theory also tells at some point that the money supply does not affect other variables of employment and output. It says that money supply is exogenous and is not affected from changes in demand for money (Hagemann, 2016).

The other theories pertaining to this concept also share the same variables as the determinants of money. According to Brady (2018) the money demand theories focuses on the relationship among the quantity demanded of money and few economic variables that links to economy of the country. For instance, Keynes theory of liquidity preference describes the main motive of the need of holding money and its demand. These motives are transactional, precautionary and speculative motives. The transactions motive tells the need of holding money for daily transactions of individuals to satisfy their needs. Meanwhile, precautionary motive relates to the need of holding money for dealing with transactions for emergency purposes such as accidents, sickness or danger of unemployment. Lastly money is held for speculative purposes to take the advantage of movement in exchange rate. For example, if dollar appreciates in the future, an individual holding dollar can sell his money to gain more or buy more at cheaper rates.

Tobin's theory of money demand tells that individuals hold a portfolio of assets with money interest bearing bonds. Hence while keeping a portfolio, an investor decides of how much of his assets should be kept as interest bearing bonds giving them higher returns and the ones with zero returns. They money demand theory of Baumol focuses on inventory-based approach in which such demand is relied upon for executing dealings. The inventory of money is held for carrying out the day to day transactions of an individual. However, holding money results in consumers bearing a cost of interest rate forgone which they could have earned if the money was deposited in financial institutions (Thompson, 2016). Lastly, the demand for money according to Friedman (1956) tells that individual's wealth depends on the balances they are retaining and the returns they are expecting from equity and affects from movement in inflation rates.

\subsection{Empirical Study of Demand for Money}

According to various studies relating to the demand for money, it has been concluded that the demand for money is raising in countries. For instance, South Africa, Turkey and many other countries have a rising demand for money. According to the study of Baidoo and Yusif (2019), a co-integrated connection exists among the cash balance and its variables. While some other studies give importance to other variables of demand for money or other approaches. For example, Chavula (2016) reported other determinant of money in terms of GDP, inflation/ unemployment rate, interest/ exchange rates etc. stated that money's demand is dependent on various factors. Overall the major focus has been placed on the link amongst interest rate, inflation and level of income in determining the money demand.

Moreover, according to the demand for money, it is also important to maintain its stability in monetary terms as a stable demand of money possess a predictable demand that can be measured and accurate forecasts can be made out of it. However, the predictability changes if a lot of knowledge is required for numerous variables. While on the other hand the money should have appropriate links to consumption and other economic activities being taken place (Nduka, 2014; EmenikeKalu and Obasi, 2016; Arora and Osatieraghi, 2016; Iyede, Onah and Agu, 2018; Sultana, Koli and Firoj, 2019; Rehan, Chhapra and Zain, 2019; Emmanuel, et.al. 2019; Okolo, Irem and Ugwuoke, 2019; Monogbe, et.al. 2019; Nzeribe, 2019; Rahman, 2019; Salim, 2019). Hence it can be obtained from the literature that 
a lasting relationship is presented between money supply, the real GDP, inflation and interest rate and movements in exchange rate. All these variables are also necessary to take into account when predicting the demand and supply of money for obtaining more realistic results.

\section{Data and Method}

For conducting this study, the researcher has opted for quantitative design as Kumar (2019) stated that quantitative design is based on systematic underpinnings that include statistical analysis and use of statistical tools for achieving the study objectives. Hence, quantitative design has been adopted in which data has been collected by using secondary data. This will allow the researcher to generalise the data deductively and use statistical analysis for drawing conclusions from the findings. The secondary data has been collected from the World Bank's reports, websites and other country reports. The data from 1990 to 2017 has been collected on real asset price index, GDP deflation, Real GDP, long-term interest rate, short-term interest rate and consumer price index. After collecting the data, the researcher has conducted correlation and regression analysis with the help of Eviews statistical tool. These tests have been conducted for testing the following equation:

$\log \left(\mathrm{M}_{1}\right)=\alpha+\beta_{1} \log (\mathrm{GDP}$ DEF $)+\beta_{2}(\log \mathrm{R}-\mathrm{GDP})+\beta_{3} \mathrm{AP} / \mathrm{P}+\beta_{4} \mathrm{RL}+\beta_{5} \mathrm{RS}+\beta_{5} \mathrm{CPI}+\varepsilon$

Where,

$\mathrm{M}_{1}=$ Broad Money

$\mathrm{AP} / \mathrm{P}=$ Real Asset Price Index

GDP DEF= Gross Domestic Product Deflation

R-GDP $=$ Real Gross Domestic Product

$\mathrm{RL}=$ Long-term Interest Rate

$\mathrm{RS}=$ Short-term Interest Rate

$\mathrm{CPI}=$ Consumer Price Index

The study uses different statistical techniques and robust analysis to select an appropriate model to evaluate money demand function of the Philippines. For this purpose, descriptive statistics was applied to shed light on the characteristics of the variables; but to determine how certain macroeconomic variables are affecting the money supply in the country, then ordinary least square (OLS) was a most suitable and easiest statistical technique to apply (Schneider, Hommel and Blettner, 2010). The data did not meet with the basic assumptions of the regression; hence regression was not applicable with respect to the data of study (Williams, Grajales and Kurkiewicz, 2013. Therefore, the methodology of the study was then diverted to vector autoregressive (VAR) modelling, but to apply VAR model, there is basic assumption of stationarity of the data (Lütkepohl, 2013). However, Augmented Diceky-Fuller test provided unfavorable results that showed that there is unit root in the variables such as short-term interest rate (RS), real GDP, Broad money, inflation, and real asset price index (AP/P) have unit root. Therefore, the methodology was then diverted towards co-integration and granger causality that can be used with the variables having unit root (Papana et al., 2014). Therefore, co-integration and Granger Causality tests were used in the following data to examine

\section{Results}

\subsection{Descriptive}

Descriptive statistics are measured and presented with intention to put shed light on the all variables of the study, and their basic characteristics in case of Philippines. Table 1 below shows the descriptive statistics of the variables.

Table 1. Descriptive statistics

\begin{tabular}{lrrrrrr}
\hline Descriptive & \multicolumn{1}{c}{ LN_M1 } & \multicolumn{1}{l}{ LN_RGDP } & \multicolumn{1}{l}{ GDP_DEF } & \multicolumn{1}{l}{ AP_P } & \multicolumn{1}{l}{ RL } & \multicolumn{2}{l}{ RS } \\
\hline Mean & 28.64606 & 29.12855 & 5.644095 & 77.5232 & 4.816824 & 11.13814 \\
\hline Median & 28.6903 & 29.08426 & 5.516887 & 73.85892 & 4.777425 & 9.778667 \\
\hline Maximum & 30.24185 & 29.85097 & 16.52688 & 126.4763 & 10.6978 & 24.11808 \\
\hline Minimum & 26.63384 & 28.6185 & -0.58657 & 28.58481 & -4.57937 & 5.525917 \\
\hline Std. Dev. & 1.041593 & 0.385446 & 3.6011 & 29.54483 & 2.87895 & 5.219333 \\
\hline
\end{tabular}


The mean of broad money (M1) is $28.68 \%$ percent implying that board money on average rises by $28.68 \%$ in Philippines. Meanwhile, during the period 1990-2018, maximum M1 was 30.24\%, and minimum M1 was 26.63\%; this shows that within that time period, Philippine's board money has increased by $28.68 \%$ on average. Meanwhile, the standard deviation of the board money is $1.04 \%$ by which broad money supply can increase and decrease. Since, standard deviation is very low, hence it is evident that broad money growth in the Philippines is constant over a period time. This means there are fewer fluctuations in the broad money and this makes variable more effective.

In addition to this, change of real GDP of the Philippines is $29.12 \%$; where minimum and maximum values were $28.61 \%$ and $29.85 \%$. This indicates that on average the real GDP of Philippines has increased by $29.12 \%$ on average, and in same period it has went highest growth rate of $29.85 \%$, and minimum growth during the period was $28.61 \%$. This indicates that real GDP change of the Philippines is exceptionally high, making the country one of fastest growing country in terms of real GDP. Meanwhile, the standard deviation of the real GDP is $0.38 \%$ which is significantly lower, and implies that real GDP has been increasing almost at constant rate, and that is the reason behind lower standard deviation.

Furthermore, the mean GDP deflator of the Philippines is 5.64\% and it has standard deviation $3.60 \%$ by which the mean GDP deflator might increase or decrease. During the period, maximum and minimum GDP deflator was $16.52 \%$ and $-0.5 \%$; therefore, it can be interpreted as that on average the mean value of prices in Philippines has increased by $5.64 \%$. Since, standard deviation of the deflator is $3.6 \%$, hence it can be stated that this value by which deflator might increase or decrease. This is indicates higher fluctuations in the GDP deflator, and that GDP deflator might not be consistent over time. Furthermore, mean Real Asset Price Index (AP/P) of the Philippines is 77.52 which reflect to the change in the price level as compared to bench $2012=100$; this indicates a decline in the price level. Meanwhile, standard deviation of the AP/P is 29.54 by which the mean value might increase or decrease; and it shows there is inconsistency in the GDP deflator and depends on the inflation inside the country over a specific time frame.

Furthermore, mean long-term interest (RL) of the Philippines was $4.81 \%$ that has standard deviation 2.84\%; and during the period minimum long-term interest was $10.69 \%$ and minimum long-term interest rate was $-4.57 \%$. Based on the these descriptive statistics, it can be determined that long-term interest rate of the Philippines is $4.81 \%$ on average, but this mean value might improve or decline by $2.87 \%$ standard deviation. This implies that in Philippines if a business acquires funds or financing for long-term period, then it has pay on average $4.81 \%$ interest annually. In contrast, the mean short-term interest rate of Philippines is $11.13 \%$ that has standard deviation $5.21 \%$, and this implies if a business require short-term funds then it has to pay an interest rate of $11.13 \%$ which may vary by standard deviation 5.21\%. This indicates that investors in Philippines do not expect a future growth from economy, and this is also major reason that interest rate of short-term loan is higher than long-term interest rate.

\subsection{Pearson's Correlation}

Table 2. Pearson's correlation

\begin{tabular}{lr}
\hline Correlation & \\
\hline Probability & LN_M1_ \\
\hline LN_M1_ & 1.00 \\
\hline Prob. & 1.00 \\
\hline LN_RGDP_ & 0.97 \\
\hline Prob. & 0.00 \\
\hline GDP_DEF & -0.84 \\
\hline Prob. & 0.00 \\
\hline AP_P & 0.99 \\
\hline Prob. & 0.00 \\
\hline RL & -0.50 \\
\hline Prob. & 0.01 \\
\hline RS & -0.94 \\
\hline Prob. & 0.00 \\
\hline
\end{tabular}


According to the given data, it can be seen that a strong relationship exists among the real GDP of the economy and the supply of money because the coefficient correlation is greater than 0.5 . This means that as a strong relationship between the two variables exists, this tells that as the supply of money increases, consumers will have more money to spend on in the economy and in this way consumption would increase (Gogtay and Thatte, 2017). As demand for goods will increase due to increased consumption by consumers, this will further increase productivity levels which would finally contribute towards the real GDP of the economy which would also increase with increase in supply of money.

In terms of GDP-DEF and money supply, there is an inverse affiliation amongst the two variables which means there is a negative correlation. Given that GDP-DEF increases it is likely that LNM1 will decrease and vice versa. Furthermore, the magnitude of the coefficient is -0.83 or $-83 \%$ therefore, it is inferred that there is strong covariance between the two variables. Finally, the significance value is 0.000 which is less than 0.05 and thus the correlation is significant statistically.

In case of the connection amongst APP and LNM2, the sign of the coefficient of correlation is positive and therefore it can be inferred that there is positive correlation or covariance. Given that APP increases, it is likely that LNM1 will also increase and vice versa. Furthermore, the magnitude of the coefficient is .985 or $98.5 \%$ which is higher than 0.5 or $50 \%$. Therefore, it is inferred that there is strong covariance between the two variables. Finally, the significance value is 0.000 which is less than 0.05 and thus the correlation is statistically significant.

In case of relationship between RL and LNM1, the sign of the coefficient of correlation is negative and therefore it can be inferred that there is inverse correlation or covariance. Given that RL increases it is likely that LNM1 will decrease and vice versa. Furthermore, the magnitude of the coefficient is -0.5 therefore, it is inferred that there is moderate covariance between the two variables. Finally, the significance value is 0.000 which is less than 0.05 and thus the correlation is statistically significant.

For RS and LNM1, the sign of the coefficient of correlation is negative and therefore it can be inferred that there is inverse correlation or covariance. Given that RL increases it is likely that LNM1 will decrease and vice versa. Furthermore, the magnitude of the coefficient is -0.94 . Therefore, it is inferred that there is strongly negative covariance between the two variables (Akoglu, 2018). Finally, the significance value is 0.000 which is less than 0.05 and thus the correlation is statistically significant.

\subsection{Unit Root Test}

Unit root test is used to determine either data is stationary or not stationary; or this is a problem with the data itself when there is systematic pattern in the data. The pattern in the data makes it is impossible to forecasts future values based on the fact that unit root is present in the data, and it makes it impossible to forecast future values (Reed, and Smith, 2017). Meanwhile, the core concept of the unit root is that there is random walk in the trend, and it is entirely impossible to predict the random walk. Therefore, when there is random walk in the data, then it makes the data non-stationary and that unit root is present in the data (Salisu and Adeleke, 2016). Meanwhile, in order to determine whether there is stationary in the money demand function variables; Augmented Dickey-Fuller test was used to examine stationarity of the data. Table 3 presents the results of unit root test.

Table 3. Augmented Dickey-Fuller (ADF) unit root test

\begin{tabular}{lrl}
\hline Augmented Dickey-Fuller test statistic & t-Statistic & Prob. \\
\hline Short-term Interest Rate (RS) & -2.78 & 0.07 \\
\hline Long-term Interest Rate (LS) & -5.45 & 0.00 \\
\hline Real GDP (LN_RGDP) & 3.80 & 1.00 \\
\hline Broad Money (LN_M1) & -2.77 & 0.08 \\
\hline GDP Deflator & -3.72 & 0.01 \\
\hline Inflation (CPI) & -3.00 & 0.05 \\
\hline Real Asset Price Index & -0.12 & 0.94 \\
\hline
\end{tabular}

The null hypothesis of the ADF test is that there is unit root in the data, and null hypothesis of the ADF test is that there is no unit root in data. Based on this hypothesis, the t-statistic and probability value for all variables is presented in the table above. There are only two variables that have probability value less than alpha 0.05 implying 
that there is evidence of no unit root, and these variables are long-term interest rate (LS) and GDP deflator with probability value of 0.00 and 0.01 . Therefore, it can be sufficiently stated that long-term interest rate (LS) and GDP deflator do not have unit root, and these two variables can be estimated since there is no systematic pattern or random walk that cannot be predicted. In addition to this, other variables which include; short-term interest rate (RS), real GDP, Broad money, inflation, and real asset price index have probability value greater than alpha 0.05 forcing not reject null hypothesis that data has unit root. Since, there is unit root in the majority of the variables, and broad money itself hence it is not possible to predict future values. Therefore, application of regression or VAR is not applicable in scenario, Johansen Co-integration and Granger Causality is a way to effective deal with the non-stationary data.

\subsection{Co-Integration}

Cointegration is also a statistical technique used to examine the time series data which is non-stationary in nature. The core concept behind cointegration is to see if there is long-run relationship between the movements of variables over a period of time. In presence of long-run interrelation between the variables implies that two variable's movement is mutually influenced by movement of each other's variable (Dwyer, 2015; Ahmed et al., 2017). In following example, the cointegration is used to determine if the money demand function's movements have mutual interrelation with the other macroeconomic indicators. Therefore, if there is no cointegration then it is sufficient to state that selected macroeconomic indicators do not have long-run mutual relationship. Hence, absence of long-run interrelation is indication that macroeconomic indicators cannot predict broad money. However, if there is cointegration of Broad money (M1) with selected macroeconomic indicators then it can be sufficiently stated that there is long-run relationship that can estimate the broad money in future based on the past values. Table 4 presents the result of Johansen cointegration.

Table 4. Johansen cointegration

\begin{tabular}{lrrr}
\hline Hypothesized & Trace & \multicolumn{2}{c}{0.05} \\
\hline No. of CE(s) & Statistic & Critical Value & \multicolumn{1}{c}{ Prob.** } \\
\hline None $*$ & 225.93 & 125.62 & 0.00 \\
\hline At most $1 *$ & 136.24 & 95.75 & 0.00 \\
\hline At most 2* & 94.16 & 69.82 & 0.00 \\
\hline At most 3* & 56.00 & 47.86 & 0.01 \\
\hline At most 4 & 25.28 & 29.80 & 0.15 \\
\hline At most 5 & 10.66 & 15.49 & 0.23 \\
\hline At most 6 & 3.43 & 3.84 & 0.06 \\
\hline Trace test indicates 4 cointegrating eqn(s) at the 0.05 level & & & \\
\hline$*$ denotes rejection of the hypothesis at the 0.05 level & & & \\
\hline
\end{tabular}

The Johansen cointegration results show that that four cointegrating equations are present at significance level 0.05; this indicates that selected macroeconomic indicators have mutual movement with the other variables. However, Johansen cointegration cannot specifically highlight which variable has cointegration, but it only examines either there is cointegration or not. Since, this test provides sufficient evidence to believe that there is cointegration between the variables, hence it needs to be further analyzed that among which selected variables there is co-integration. However, as of cointegration results it is clear that there is cointegration within the some of the variables, now it is to be identified which of those variables' movements have a long-run relationship.

\subsection{Granger-Causality}

Granger Causality is a statistical method to approach to determine causality between the variables of the time series even when there is unit root in the data. The core concept behind the Granger causality is to identify the patterns of relationship between the variables in the data, and then determine causality of the variables (Ahmed et al., 2017). The Granger Causality is somehow based on the cause-and-effect idea; but is not entirely related to this. Therefore, the assumption of the Granger Causality is that lagged values of $\mathrm{x}$ can explain the variation in the lagged values of $\mathrm{y}$; if this is true then there is cause and effect (Papna et al., 2014). Hence, movements in the y values can be explained 
or predicted through movement in $\mathrm{x}$ values. Meanwhile, the null hypothesis of the Granger Causality can be explained as for instance that variable $\mathrm{x}$ does not Granger Cause variable $\mathrm{y}$, and alternative hypothesis is variable $\mathrm{y}$ does not Granger Cause variable $\mathrm{x}$.

Based on same example, the results of the Granger Cause have been presented in Table 5 as follows.

Table 5. Granger-Causality

\begin{tabular}{|c|c|c|c|c|}
\hline & Pairwise Granger Causality Tests & & & \\
\hline No. & Null Hypothesis: & Obs. & F-Statistic & Prob. \\
\hline 1 & LN_M1_does not Granger Cause RS & 27 & 6.6611 & 0.0055 \\
\hline 2 & RS does not Granger Cause LN_M1_ & & 0.44153 & 0.6486 \\
\hline 3 & LN_M1_does not Granger Cause RL & 27 & 3.70459 & 0.0411 \\
\hline 4 & RL does not Granger Cause LN_M1_ & & 0.02037 & 0.9799 \\
\hline 5 & LN_M1_does not Granger Cause LN_RGDP & 27 & 0.29735 & 0.7457 \\
\hline 6 & LN_RGDP_does not Granger Cause LN_M1_ & & 2.37945 & 0.116 \\
\hline 7 & CPI does not Granger Cause LN_M1_ & 27 & 0.57931 & 0.5686 \\
\hline 8 & LN_M1_does not Granger Cause CPI & & 4.73517 & 0.0195 \\
\hline 9 & GDP_DEF does not Granger Cause LN_M1_ & 27 & 0.7731 & 0.4737 \\
\hline 10 & LN_M1_does not Granger Cause GDP_DEF & & 8.11976 & 0.0023 \\
\hline 11 & AP_P does not Granger Cause LN_M1_ & 27 & 2.92446 & 0.0748 \\
\hline 12 & LN_M1_does not Granger Cause AP_P & & 0.42729 & 0.6576 \\
\hline
\end{tabular}

The first pairwise Granger Causality test examines Granger Causality of M1 with short-term interest rate (RS), and p-value of the test is 0.00 which suggest rejecting null hypothesis which means M1 do Granger Cause RS. However, second hypothesis is rejecting which means short-term interest rate can be not be used to predict the M1. Similarly, considering the all 12 hypothesis, it is found that M1 can cause long-term interest rate, M1 can cause CPI and M1 can cause GDP deflator. Therefore, it can be determined that all macroeconomic variables which includes short-term interest rate (RS), long-term interest rate (LS), consumer price index (CPI), GDP deflator, real GDP (RGDP) and Real Asset Price Index (AP/P) do not granger cause broad money (M1). This means these variables cannot be used to predicted the broad money (M1).

Based on the result of Granger Causality, it can be interpreted that selected macroeconomic variables does not cause an effect in the broad money; this means RS, LS, CPI, GDP deflator, RGDP and AP/P cannot predict the lagged values of broad money. This shows money demand function in Philippines is not affected by the all selected macroeconomic variables. However, with regard to estimation of money supply function, Narayan, Narayan and Mishra (2009) attempted to examine money supply function of south Asian countries, and study found that all countries have stable money demand function except the Nepal. Similarly, in case of following study, the money demand function of Philippine cannot be stated as stable since no macroeconomic variable was to have granger cause broad money (M1).

\section{Conclusion}

Monetary policy is one of important macroeconomic indicator and instrument of central banks to regulate money supply in country. Money demand function, therefore plays a central role for the policy makers to examine what need to be targeted either money or interest rate. Higher money supply in the market tends to influence consumer price index (CPI), but also boosts consumption and positively affects country's output. Hence, money supply is an indicator that is also influenced and influences other macroeconomic indicators; thus in presence of positive and negative relationship between the indicators could be used to predict and forecasts the money supply and assist 
policy makers. With this intention following study was conducted to examine money demand function of Philippines; and it is found that there is cointegration between the macroeconomic indicators. The results of cointegration reveals there is presence of linear combinations, and results shows that there are four cointegrating equations present. Therefore, it is evident that there are at least 4 cointegrating relations between the variables. Hence, some of macroeconomic indicators can be used to predict the broad money due to presence of vector. However, the Granger-Causality shows that no macroeconomic variable granger cause broad money (M1). Therefore, the selected macroeconomic indictors RS, LS, CPI, GDP deflator, RGDP and AP/P cannot be used to predict the variation in the broad money (M1) in case of Philippines. This means the money demand function in Philippines is not stable, and for this purpose further investigation is suggested by increasing sample size, and time window in quarterly or semi-annually.

\section{References}

Ahmed, R. R., Vveinhardt, J., Streimikiene, D., \& Fayyaz, M. (2017). Multivariate Granger causality between macro variables and KSE 100 index: evidence from Johansen cointegration and Toda \& Yamamoto causality. Economic Research-Ekonomska Istraživanja, 30(1), 1497-1521.

Akoglu, H. (2018). User's guide to correlation coefficients. Turkish Journal of Emergency Medicine, 18(3), 91-93.

Arora, N., \& Osatieraghi, A. (2016). Does India have a stable demand for money function after reforms? A macroeconometric analysis. Прикладная эконометрика, 4(44).

Baidoo, S. T., \& Yusif, H. (2019). Does Interest Rate Influence Demand for Money? An Empirical Evidence from Ghana. Economics Literature, 1(1), 24-36.

Brady, M. E. (2018). The Keynes-Hawtrey Exchanges of February and March, 1936 in Volume 14 of the CWJMK: Keynes's Theory was NOT that the Supply and Demand for Money Alone Determined the Rate of Interest. Available at SSRN 3119463.

Chavula, H. K. (2016). Monetary Policy Effects and Output Growth in Malawi: Using a Small Macroeconometric Model. Open Journal of Modelling and Simulation, 4(4), 720-726.

Dimand, R. W. (2019). Revitalizing the Quantity Theory of Money: From the Fisher Relation to the Fisher Equation. In Irving Fisher (pp. 45-73). Palgrave Macmillan, Cham.

Dwyer, G. P. (2015). The Johansen tests for cointegration. White Paper.

Edet, B. N., Udo, S. U., \& Etim, O. U. (2017). Modelling the Demand for Money Function in Nigeria: Is There Stability?. Bulletin of Business and Economics (BBE), 6(1), 45-57.

EmenikeKalu, O., \& Obasi, R. (2016). Long-run relationship between marketing of bank services \& the performance of deposit money banks in Nigeria. International Journal of Economics, Business \& Management Studies, 3(1), $12-20$.

Emmanuel, U., Udoh, B. E., Prince, A. I., Okoh, J., \& Ndu, O. M. (2019). Money Supply and Inflation Rate in Nigeria: The Missing Link. Humanities and Social Sciences Letters, 7(3), 156-166.

Gogtay, N. J., \& Thatte, U. M. (2017). Principles of correlation analysis. Journal of the Association of Physicians of India, 65(3), 78-81.

Hagemann, H. (2016). Irving Fisher (1867-1947). In Handbook on the History of Economic Analysis Volume I. Edward Elgar Publishing.

Inoue, T., \& Hamori, S. (2008). An empirical analysis of the money demand function in India. Institute of Developing Economies Discussion Paper, 166.

Iyede, R. O., Onah, F. E., \& Agu, C. C. (2018). A Survey of Studies on Money Demand and Inflation Amidst Banking Crisis. Journal of Accounting, Business and Finance Research, 2(2), 34-54.

Jonung, L. (2018). Demand for money: an analysis of the long-run behavior of the velocity of circulation. Routledge.

Keynes, J. M. (1936). The general Theory of Employment, Interest and Money. London and New York, Macmillan.

Kumar, R. (2019). Research methodology: A step-by-step guide for beginners. Sage Publications Limited.

Lütkepohl, H. (2013). Vector autoregressive models. In Handbook of Research Methods and Applications in Empirical Macroeconomics. Edward Elgar Publishing. 
Monogbe Tunde, G., Austin, A., Uzowuru Lawrence, N., \& Edori, D. (2019). Sectoral Credit Allocation of Deposit Money Banks and Poverty Reduction in Nigeria. International Journal of Business, Economics and Management, 6(1), 49-60.

Narayan, P. K., Narayan, S., \& Mishra, V. (2009). Estimating money demand functions for South Asian countries. Empirical Economics, 36(3), 685-696.

Nduka, E. K. (2014). Structural Breaks and the Long-Run Stability of Demand for Real Broad Money Function in Nigeria: A Gregory-Hansen Approach. The Economics and Finance Letters, 1(8), 76-89.

Nzeribe, A. (2019). Appointment of Directors and Performance of Deposit Money Banks in Sub Saharan Africa: Do We Need More Executive or Non-Executive Directors?. Journal of Empirical Studies, 6(1), 1-18.

Okolo, M. N., Irem, E. N., \& Ugwuoke, C. (2019). Value for Money (VFM) Audit and Public Sector Performance in Afikpo North Local Government Area of Ebonyi State, Nigeria. International Journal of Public Policy and Administration Research, 6(2), 147-156.

Papana, A., Kyrtsou, C., Kugiumtzis, D., \& Diks, C. (2014). Identifying causal relationships in case of non-stationary time series. Thessaloniki: Department of Economics of the University of Macedonia.

Rahman, Z. U. (2019). Influence of Excessive Expenditure of the Government in Perspective of Interest Rate and Money Circulation Which in Turn Affects the Growing Process in Pakistan. Asian Journal of Economics and Empirical Research, 6(2), 120-129.

Reed, W. R., \& Smith, A. (2017). A time series paradox: Unit root tests perform poorly when data are cointegrated. Economics Letters, 151, 71-74.

Rehan, R., Chhapra, I. U., \& Zain, A. (2019). Assets Pricing and Equity Duration Paradox. Humanities and Social Sciences Letters, 7(3), 167-180.

Salim, A. (2019). Macroeconomic Determinants of Interest Rate Volatility in Indonesia: A Structural VAR Analysis. International Journal of Applied Economics, Finance and Accounting, 5(2), 101-108.

Salisu, A. A., \& Adeleke, A. I. (2016). Further application of Narayan and Liu (2015) unit root model for trending time series. Economic Modelling, 55, 305-314.

Schneider, A., Hommel, G., \& Blettner, M. (2010). Linear regression analysis: part 14 of a series on evaluation of scientific publications. Deutsches Ärzteblatt International, 107(44), 776.

Shafiq, H., \& Malik, W. S. (2018). Money Demand Function Revisited: The Role of Asset Prices in Pakistan. Pakistan Economic and Social Review, 56(1), 67-92.

Sultana, N., Koli, R., \& Firoj, M. (2019). Causal relationship of money supply and inflation: A study of Bangladesh. Asian Economic and Financial Review, 9(1), 42-51.

Thompson, N. (2016). Portfolio theory and the demand for money. Springer.

UDEH, S. N., Nwude, E., \& Offor, O. K. (2018). Determinants and stability of money demand in Nigeria. International Journal of Economics and Financial Issues, 8(3), 340-353.

Williams, M. N., Grajales, C. A. G., \& Kurkiewicz, D. (2013). Assumptions of multiple regression: Correcting two misconceptions.

Yu, H., \& Gan, P. T. (2009). An empirical analysis of the money demand function in ASEAN-5. International Research Journal of Finance and Economics, 33, 168-178. 